\title{
Turkey and the United States in the twenty-first century: friends or foes?
}

\author{
Mustafa Kibaroglu* and Tarik Oguzlu \\ Department of International Relations, Bilkent University, Ankara, Turkey
}

\begin{abstract}
Turkey and the United States for a long time treated each other as "staunch allies" during the Cold War period. The end of the East-West confrontation, however, heralded the beginning of a new era in Turkish-American relations due to the changing priorities of the long-time allies, which manifested themselves in their policies toward Iraq following the 1991 Gulf War. The divergence of approaches toward the future of the Middle East in general and Iraq in particular in the aftermath of the 9/11 attacks aggravated the tension in their bilateral relations. Had it not been for the sake of having an allied history together, "rivalry" would be the term to define the nature of the current state of affairs in Turkish-American relations. The sources of policies which have brought the two countries to the brink of wrangling are discussed in this paper. It is emphasized that the lack of a common security culture is primarily responsible for most of the trouble being encountered in their bilateral relations.
\end{abstract}

\section{Introduction}

Had Turkey and the United States not been staunch allies throughout the Cold War years, they would have easily declared each other as adversaries due to their respective foreign policies over the past several years. Since the end of the Cold War, and more specifically since 9/11, Turkey and the United States have found themselves in the middle of an undeclared rivalry. Even though the grand strategic objectives of Turkey and the United States seem to converge regarding the substance, there exist deep divergences between the two nations concerning the means and the methods of achieving these objectives. Hence, the two allies have started to come to the point of wrangling more frequently than ever in pursuit of their objectives. It would not be wrong to say that the foreign policies of the American administrations were more warmly received in Turkey when the United States was 10,000 miles away. Now that the United States has become a de facto neighbor of Turkey since the invasion of Iraq in 2003, it is seen in the Turkish public domain as the "number one enemy" and the greatest threat to national security, stability as well as territorial and political integrity.

It is interesting to note that Turkey no longer considers as its enemy Syria, which used to give ample support to the Kurdistan Workers Party (PKK) terrorist organization for nearly two decades that claimed the lives of 30,000 Turkish citizens, and formerly to the Armenian terrorist organization Armenian Secret Army for the Liberation of Armenia (ASALA), which was responsible for killing more than 30 Turkish diplomats all over the world. Neither does it consider Iran as its enemy these days, even though it was strongly accused of assassinating Turkey's secular intellectuals who had pointed out in their writings and speeches the fundamentalist threat posed to the Turkish Republic by the

\footnotetext{
*Email: kibar@bilkent.edu.tr; oguzlu@bilkent.edu.tr
} 
Iranian mullah regime. ${ }^{1}$ On the contrary, due to the "brave stance" of Iranian President Mahmoud Ahmadinejad, who is seen as not giving in to the blackmail of the United States and Israel, and also thanks to the rapprochement between the Turkish and Syrian leaderships as a result of mutual state visits, the profiles of both Syria and Iran have been elevated almost to the level of most-favored nations in large segments of the Turkish society.

Despite initiatives taken by the high-caliber individuals who played active and significant roles, on both sides, in the evolution of Turkish-American strategic relations, such as former diplomats and statesmen - as well as the institutional interventions by the leading think tanks and non-governmental organizations, such as the trade chambers and business unions - the outlook for their bilateral relations does not seem to be promising for the years and decades to come. This is an anomaly, considering the fact that the two nations were, and still are, among those who would benefit the most by pursuing congruent policies with one another regarding the same problem areas, such as terrorism and nuclear weapons proliferation, which are defined by both of them as posing the greatest threats to their national security.

The current crisis of confidence in Turkish-American relations cannot solely be attributed to the current leaderships in both countries. Thus, the expectation that their relations may soon improve with the change of government in either or both countries should not be accepted at face value. The ongoing crisis owes its existence to much deeper factors, of which the growing rift between the strategic cultures of both countries comes first. Unless the strategic gap is narrowed, the years ahead may be fraught with new crises and dwindling cooperation.

Hence, the core attributes of the Turkish and American strategic cultures in dealing with the challenges and threats to their national security, where the essence of the problem seems to lie, must be carefully studied. This is important, for the dynamics of the Cold War-era politics for a long time concealed the strategic differences existing between Ankara and Washington. Turkish and American decision-makers have long believed that their common threat perceptions would continue to guarantee their security cooperation within the context of the North Atlantic Treaty Organization (NATO) and elsewhere in the world, even after the disappearance of the threat posed by the former Soviet Union. Decades of close and intense cooperation in the military-strategic domain led observers to believe that both countries subscribed to a common strategic mentality.

However, the developments that took place in the aftermath of the collapse of the bipolar international system, and then the dynamics of the post-9/11 era, have made it quite clear that Turkey and the United States did not see eye to eye on several strategic issues. The fact that the United States is the most important actor across the globe having an hegemonic agenda, and Turkey is a mid-sized power in its regional environment trying to protect itself against the uncertainties of the new era, has gradually shaped the current strenuous nature of bilateral relations. In the two decades that followed the end of the Cold War, both countries have gradually drifted apart in terms of the ways and means of achieving their strategic objectives, despite their high degree of congruence in substance.

To cite a few reasons for this trend, both Turkey and the United States had to deal with terrorism more frequently and intensively in the post-Cold War era than ever before. Terrorism has become an inescapable problem for both nations due to the changing international security environment. Notwithstanding the similarity of the problems that Turkey and the United States face, it is difficult to argue that the degree of cooperation between them in dealing with the threat of terrorism is at the level that would be expected from "staunch allies." On the contrary, falling short of meeting the expectations of each 
other has become a serious source of friction and even a bone of contention between the two countries.

In the same vein, both Turkey and the United States are concerned with the rise of political Islam in the world. Turkey, being a secular state in terms of its Constitution, which was created in 1923 out of the ashes of the Ottoman Empire following the War of Liberation at the end of World War I against the occupying powers, is most sensitive about the separation of the state and religion in the administration of the country. Similarly, the United States is complaining about the role that Islam has started to play in many more countries in the world where there exist significant proportions of Muslim communities. Hence, both Turkey and the United States agree that politicization of Islam must be tackled somehow. Nevertheless, both countries have deep disagreements on how to achieve this goal. Moreover, the role that the United States expects Turkey to play due to its Muslim character creates deep resentments among the secular elite in Turkey, with the military being at the forefront.

More recently, the crisis in the Caucasus that erupted with the Russian military intervention in South Ossetia and Abkhazia districts of Georgia in August 2008, paving the way for the proclamation of independence by these two autonomous regions and the prompt recognition of their independence by Russia, revealed the divergent approaches of Turkey and the United States vis-à-vis a common potential threat, namely the resurgence of aggressive policies of Russia. The response of the United States to the Russian invasion of the Georgian territory included, among others, sending its naval vessels into the Black Sea, which made the Turkish authorities feel rather uneasy about its possible implications for Turkey and the Montreux Convention of 1936, which regulates the passage of military vessels through the Turkish Straits and the duration of their stay in the Black Sea. Had such a development happened during the Cold War, the Turks might not have worried this much about the presence of American maritime power patrolling in the Black Sea and showing its flag to the Soviets. Nevertheless, today the meaning of the presence of the U.S. naval vessels in the Black Sea has a different significance from Turkey's perspective.

Against this background, this article seeks to provide answers to the following questions: What are the main aspects of the Turkish and American strategic cultures, respectively? How do they define security in general and terrorism in particular? What are the reasons for adopting divergent ways and means in their fight against terrorism? Does the vision of global politics of the United States match up with the core values of Turkey well into the twenty-first century? Can Turkey's aspirations to join the European Union (EU) be explained by the dynamics of its deteriorating security relationship with the United States? To what extent do their expectations from NATO converge or diverge? And finally, what impact may the Russian military intervention in Georgia have on the perceived value of the United States as an ally in the eyes of Turkish policy-makers?

\section{Terrorism as a dividing or uniting force?}

The growing strategic divergence between Turkey and the United States becomes evident when one focuses one's attention on the way in which these countries define terrorism and the means to deal with it. Despite all their horror, the 9/11 attacks did not lead to a wholesale Turkish acceptance of the American conceptualization of terrorism. To Washington, today's new age terrorism is fundamentally different from the old conceptualizations - in the sense that it is more than ever before driven by religious ideologies and that the main goal of these terrorists is to annihilate their opponents. New age terrorists are difficult to deter for they are not necessarily rational decision-makers. ${ }^{2}$ 
How would it be possible to deter or dissuade someone from committing his or her act if that person is resolved to die for the sake of a sacred goal? Moreover, new age terrorists are not concentrated in a specific geographical location, they operate across loose transnational networks, benefiting from advanced information technologies as much as possible, and they no longer have identifiable or traceable hierarchical organizational structures in terms of command and communication. New age terrorism, particularly the Al Qaeda version, is more religious than political. When goals are defined in religious terms, it becomes more difficult to engage new age terrorists through dialogue or political maneuvers.

In the eyes of U.S. decision-makers, the new age terrorism, as represented by Al Qaeda, poses a grave threat to the American way of life. At stake are the core American values. ${ }^{3}$ Americans conduct their struggle against new age terrorism as if they are at war, suggesting that there are only two possible outcomes; either total victory or total submission. When this struggle is defined as a war, then the use of brute force becomes a legitimate instrument to employ. To Washington, countries that harbor terrorists or offer them logistical support are equally guilty of endangering American national security interests. Therefore, their destruction through war is undoubtedly legitimate.

Sheer power asymmetry between the United States and its rivals, both state and nonstate actors, has long led the American policymakers to believe that the United States would be exempt from existential security threats. The assumption was that the United States would not be vulnerable to outside threats, thanks to the strategic advantage provided by the oceans on both sides of the continental state, and its superior military capabilities would help deter potential challengers. These factors have played significant roles in that the threshold of tolerating terrorism, of whichever kind, has always been low on the part of Washington. ${ }^{4}$ The more powerful the United States turned out to be, the less tolerant it became toward living with terrorism.

Hard power capability has also resulted in a muscular approach in the fights against terrorism. That is to say, the United States tended to adopt more military, less police and civilian instruments in coping with the terrorism challenge. The need to understand the structural causes of terrorism has been generally overlooked. Victory against terrorism has been defined in terms of numbers of terrorists being killed or captured. That said, the September 11 attacks served as a warning call for the increasing necessity to pay more attention to the underlying dynamics of terrorist activities, either local or global. Since then, it appears that the U.S. foreign- and security-policymakers have been defining the American grand strategy in light of global terrorism.

In contrast to the United States, Turkey views terrorism as more of a security problem caused by the employment of military instruments by a group of terrorists driven by what they believe to be achievable political goals. To Ankara, terrorism does still operate in its classical framework, and terrorists can therefore be deterred. The most important challenge in this context stems from the "Kurdistan Workers Party", known as the PKK in Turkey. The PKK is a classical terrorist organization employing brutal and violent means in order to help bring into existence an independent Kurdish state in Turkey's southeastern region. Since the head of the organization, namely Abdullah Ocalan, was put in prison in 1999, the PKK appears to have redefined its goal as to help enforce the reshaping of the Turkish Republic in line with the idea of democratic confederalism. According to this Kurdish separatist ideology, the Turkish Constitution should be rewritten in such a way that would reflect that Turkey consists of two constituent communities, namely the Turks and the Kurds, and that the latter should be allowed to govern its autonomous region in southeastern Anatolia. 
In the eyes of Turkish security elites, the causes of PKK terrorism are both domestic and from abroad. However, the fact that the Kurdish citizens of Turkey suffer owing to structural problems at home should in no way justify the revolt of the PKK terrorists against the legitimate political authority in Ankara. The majority of Turkish citizens, regardless of their ethnic backgrounds or the regions where they live, do also suffer due to similar structural problems. Yet, they do not take up arms against the central authority of the Turkish state. It has also been assumed that regional or systemic actors have long been manipulating the PKK terrorism in order to increase their leverage vis-à-vis Turkey. ${ }^{5}$

Based on its decades long struggle against the PKK, Turkey does now appear to have a well-defined culture of how to define terrorism, as well as getting to know how to deal with it. Turks are somehow used to living with terrorism and the threshold of tolerating terrorism is much higher than that of the United States. Turkey also prioritizes the employment of military means in its struggle against terrorism-similar to the United States. However, there is also a strong consensus at home that without eradicating the structural causes of terrorism through socio-economic policies, the fight against the PKK may never be won.

The aftermath of the U.S.-led war in Iraq has made it quite clear that Turkey and the United States think differently as to how to define as well as to deal with the PKK terrorism. Turkey considers this organization as the most important threat posed to its national security and unity, and thinks that it is entitled to resort to every possible legal means available to eradicate this threat. In this sense, Turkey has grown unhappy with the fact the regime change in Iraq has provided the PKK with the possibility of using northern Iraq as a logistical safe haven. Adding insult to injury, Turkey felt frustrated whenever the United States government asked Ankara not to launch military incursions into northern Iraq in pursuit of the terrorists. Washington has long refused to give the green light to Turkish operations in the region lest such operations might destabilize this comparatively more stable part of post-war Iraq. In the eyes of the Washington administration, securing strategic cooperation with the Iraqi Kurds during the postwar reconstruction and statebuilding period in Iraq has long appeared to be more important than aiding one of the staunchest allies in NATO, namely Turkey, in its fight against the PKK.

That said, Turkey and the United States resolved some of their differences over the ways and means of dealing with the PKK terrorism to some extent during the visit of Turkish Premier Recep Tayyip Erdogan to the White House to meet with President George W. Bush in October 2007. Both leaders have declared the PKK to be the common enemy of both nations and also agreed to share "actionable intelligence" in order to effectively fight against this terrorist organization. Based on this thaw, Turkey organized airstrikes against the PKK targets in northern Iraq in late 2007 and limited land operations in the region in early 2008. Noticeable in Turkey's action was that Ankara exploited nearly all available non-military options before undertaking such operations and that securing international legitimacy appeared to have been valued more than ever. Ankara has also tried to gain the consent of the Iraqi Kurdish leadership by making it as clear as possible that the attacks would be short-lasting and aimed at only the PKK targets.

However, much still needs to be done to close the gap between the United States and Turkey. While Washington mainly sees the PKK terrorism as Turkey's domestic problem and asks Ankara to find a solution to it within the framework of improving human rights and liberal democracy, Ankara argues that the resilience of the PKK terrorism is very much related to the political dynamics in northern Iraq. Moreover, Ankara views the politicization of the PKK terrorism through skeptical eyes, and accuses the United States of turning a blind eye toward its sensitivities. While Washington approaches the PKK issue 
from an instrumental and tactical point of view, the PKK terrorism touches the very core of Turkey's security interests. Furthermore, while Turkey defines Al Qaeda as a terrorist organization and helps the United States win its war in Afghanistan, Ankara does at the same time shy away from defining terrorism in reference to religion. To Ankara, the attempts at defining terrorism in religious terms, by making reference to Islam in particular, not only breaches the teachings of Islam but also carries the risk of endangering Turkey's secular identity. The danger here is that the more terrorism is associated with Islam, the more Islam becomes politicized. And, the more Islam becomes politicized, the more secularism comes under challenge.

\section{Controversies over the role of religion in the new era}

One of the vital strategies to defeat religion-inspired global terrorism has been to promote liberal democracies in the Muslim-dominated states. The ultimate goal of this strategy is said to help differentiate the adherents of radical Islamists on the one hand, and the adherents of the moderate-liberal Islamists on the other. The way to prevent the radical Islamists from coming to power in their countries was thought to be possible by giving strong strategic support to the liberal Islamic voices. Washington is well aware of the fact that Islam constitutes one of the reference points of social and political life in Middle Eastern countries. Regimes that do not take their legitimacy from religion in one way or the other would likely not remain in power for long. What matters for the United States in this regard is to help engineer the development that regimes in the Middle East could take their legitimacy both from Islam and pursue a modernization/development processes in line with the constitutive norms of the Western international community - namely liberal democracy, primacy of human rights, free market economy and rule of law. Supporting the regimes which prove that Islam is not an obstacle preventing the development of friendly relations with the Western countries seems to be the most important strategy of the successive U.S. administrations against what they call radical Islamic terrorism. ${ }^{6}$ In other words, anticipating that the upsurge of Islam will result in more religious governments in the Islamic countries around the world, moderate Islam is favored by the United States in governance over radical Islam whose examples are not friendly to the Western or American way of life - as has been seen in the case of Iran since the Islamic revolution in 1979.

The support given to moderate Islamic forces by the United States in its global war on radical Islam is feared by the secular elites in Turkey, mainly because this might endanger the secular underpinnings of the Turkish Republic. To the United States, Turkey stands as a role model due to its successful combination of Islam and democracy. ${ }^{7}$ However, to Turkey's secular state elites, the characterization of Turkey by American statesmen as such to be emulated by the Islamic countries, especially those in the Middle East, in their efforts to modernize appears to run the risk of Turkey's further Islamization. The more the United States refers to Turkey's Islamic character in its role model conceptualization, the more this would contribute to the dilution of Turkey's secular identity. This is portrayed as if the conceptualization of secularism in Turkey is somehow different from the American practices and much closer to the French understanding of laicism. Not only a strong separation between state/politics and religion exists - but also, religion is understood to be a personal affair between God and the believer/individual. ${ }^{8}$ Unlike the American experience, religion in Turkey is not allowed to play a public role. While the moderate Islamization of Turkey can help the United States beat the radical Islamists in the Middle East and justify its war aims in the region, this might equally pose an existential threat to the core tenets of the secular republican regime in Turkey. 


\section{Divergence of approaches to the future geopolitics of the Middle East}

The post-Cold War era has also attested to the growing schism between the United States and Turkey concerning their regional visions. At the core lies the fact that while the United States tried to benefit from the end of the Cold War era in order to enlarge its sphere of influence across the globe, Turkey remained as a status quo power trying to protect itself against the harmful consequences of the tumultuous changes in its neighborhood. While the United States acted as a normative/imperial world power, Turkey continued to remain as a realpolitik/status quo-oriented regional power. The United States emerged from the Cold War era as the most powerful global player and began to redefine its national interests from a global perspective. Believing that its constitutive norms represent the highest standard of human development, the U.S. administrations of the past two decades have simply pursued an imperial foreign policy orientation aiming at transforming other states in the image of liberal democracy and the free market economy. ${ }^{9}$ The U.S. administrations sometimes resorted to normative means, as well as hard power instruments, in materializing American interests. The idea that spreading liberal democracy would produce more pro-American regimes across the world has led Washington to elevate the promotion of democracy to the highest place in the list of its grand strategic objectives.

This tendency became even more evident with the coming to power of the Bush administration in 2000. Despite all their tragic consequences, the terrorist attacks on September 11, 2001 also provided the United States with additional ammunition to help justify this particular foreign policy objective. For the emergence of a pro-American world order, the successive U.S. administrations tried either to impose liberal democratic transformation on weak, and failed states, or to form coalitions of democratic countries with a view to balancing the rising authoritarian regimes of Eurasia, notably China and the Russian Federation. ${ }^{10}$ Whereas the United States aimed at containing the communist Soviet Union during the Cold War era by creating a ring of pro-American security alliances across the globe, it has now been trying to contain the rising powers of Asia as well as the radical Islamist forces by engineering the creation of liberal democratic regimes in Eurasia, East Asia, and in the "Greater Middle Eastern" region. The difference between two periods is that the internal characteristics of states have lately become more critical than ever. Turning a blind eye to the ways in which states are governed internally is no longer a luxury on the part of Washington.

In contrast to the United States, Turkey has over the past two decades adopted a realpolitik/status quo-oriented strategy with a view to avoiding the negative repercussions of the changes in the systemic level on its internal order. In this regard, the post-Cold War era Turkish foreign policy can be aptly defined as being of a defensive nature, rather than aggressive or imperialist. Despite the fact that some analysts and observers wrote that Turkey's aspirations to play hegemonic and regional leadership roles in its environment have become more evident in the absence of the constraining dynamics of the Cold War era, the authors of this article believe that the motivating factor of such a policy has not been to extend Turkey's sphere of influence in a normative or imperial manner. Rather, the goal has been to help bring into existence a regional security environment in which the possibility of regional crises and instabilities affecting Turkey's domestic order would be strictly limited.

The ideal manifestation of this Turkish mentality has taken place in the aftermath of the U.S.-led war in Iraq. The fear that Iraq's implosion or dismemberment might cause insecurity at home has propelled Turkish foreign- and security-policymakers to help convene regional platforms where cooperation among Iraq's neighbors would assumingly 
mitigate regional instability. Turkey has taken a similar initiative in the aftermath of the short-lived confrontation between Russia and Georgia over South Ossetia in August 2008, by proposing the establishment of a Caucasian Stability and Cooperation Platform. The parties who have just fought each other - such as Georgia and Russia on the one hand and others who have long-standing territorial disputes over the Nagorno-Karabakh region, such as Armenia and Azerbaijan on the other hand-are cognizant of the seemingly insurmountable difficulties of bringing together the parties. In addition, there was the problem of the uneasy relations between Turkey and Armenia due to, among others, the "genocide" allegations of the latter based on the 1915 tragedy during the Ottoman Empire, so the Turkish proposal to create a platform was still more than a political demarche. It is worth noting that the key term in Turkey's proposal is the "platform," which means an open forum that does not require the parties to formally commit themselves to any particular goal in order to meet one another. In volatile regions, like the Middle East and the Caucasus, where multi-ethnic and multi-religious societies live side-by-side in a relatively small area, the alternative to diplomacy has usually been direct confrontation, which challenges regional stability and security. Hence, Turkey's proposal to establish a "platform" was another attempt to restore the status quo in the Caucasus.

Reflecting this status quo-oriented approach, the Turkish governments of the postCold War era have also viewed the U.S.-sponsored attempts in the Greater Middle Eastern region at regime change and color revolutions through skeptical eyes. The end of the Cold War era has not ended Turkey's adherence to the core values of the Westphalian international order, of which the principle of non-intervention in states' internal affairs comes first. The fact that Turkey has been going through an internal transformation process, in line with the so-called Copenhagen criteria of the European Union (EU) does not change this simple fact. The reason for this is that Turkish circles have long seen these reforms, or the EU's involvement in the republic's internal order, as the price that needs to be paid for eventual accession to the Union. Otherwise, Turkey is famous for its high degree of sovereignty sensitivity. Turks are jealous of their sovereignty. That is why the opposition to EU's involvement in Turkey's internal affairs rises whenever the prospects of Turkey's EU membership decreases, particularly owing to EU internal factors.

Turkey's discontent with the American regional vision in the Middle East has recently increased due to the growing strategic relations between the United States and the Kurds of Iraq. In Turkey's view, this picture suggests that Washington is determined to support the creation of new states in the Middle East, particularly an independent Kurdistan, with a view to diminishing the strategic isolation of Israel, the most important American ally in the region. The redesigning of regional politics in such a way to reflect the growing prominence of pro-American states does not fit in with Turkey's traditional instinct to help preserve the status quo. In Turkey's view, the possibility of an independent Kurdish state in Iraq would damage its security interests. Such a state, if created, is feared to come up with territorial claims on Turkey, and also to display a hostile attitude toward Turkey.

This fact seems to offer a strong incentive on the part of Ankara to become a member of the European Union as soon possible. It appears that the European approach toward the Kurdish question in the Middle East suits Turkey's interests better than the American approach. In the image of the European Union, the Kurdish question in the Middle East, most notably in Turkey and Iraq, should be solved within the framework of enhanced individual and minority rights. ${ }^{11}$ The EU does not have an existential problem with the current regimes. It does not seek to overthrow them by force. It sanctifies the existing territorial arrangements in the region. 


\section{Controversy over the U.S. support for Turkey in its European vocation}

With the collapse of the Warsaw Pact and the disintegration of the Soviet Union, the European Union assigned utmost priority to enlarging and deepening its integration by way of expanding its borders to the east - so as to encompass the former members of the communist bloc. Such a strategic decision of the Western European states caused further diminishing of the value of Turkey in their geopolitical and geostrategic calculations. Hence, Turkey encountered difficulties in its relations with the EU. At times when European states bluntly refused Turkey's attempts to advance its policy toward becoming a full member of the EU, the United States weighed in and did its best to convince the Europeans that it would not be a wise policy to leave Turkey out in the cold, especially in the long term. Such initiatives of the American administrations in the 1990s were welcomed in Ankara, but were found very irritating in Brussels. Yet, the United States has been very instrumental in promoting Turkey in the eyes of the European powers. In fact, the U.S. support might have delayed Turkey's accession to the EU by leading the Turkish decision-makers to believe that strong American backing and emphasis put on Turkey's geopolitical location and strategic value would suffice for the country's claim to EU membership. The possibility that Turkey's membership would first and foremost depend on the extent of the EU-related liberal democratic reforms at home might therefore have been underestimated. ${ }^{12}$

Since recently, however, the general nature of Turkish-American relations seems to have also affected the perceptions of both parties with respect to the expectations from Turkey's "Europeanization." Whereas the United States hopes to benefit from Turkey's Europeanization in terms of its strategic security interests in the so-called Greater Middle Eastern region, Turkey wants to join the EU in order to escape the adverse impact of the U.S.-led developments in the region on its security interests. The goals are completely different. The United States supports Turkey's membership of the European Union for at least four reasons: ${ }^{13}$

First, the United States hopes that the number of pro-American/NATO members of the European Union would increase following Turkey's accession that would also slow down the federal integration process inside the EU and accelerate the EU's transformation into a confederation of nation states. The possibility that the EU's international identity might be defined in opposition to the United States would likely decrease with Turkey's presence in the EU.

Second, Turkey's membership might enable the EU to play a more credible role in security and defense areas. Ankara's military contribution to the emerging European Security and Defence Policy will certainly contribute to the EU's capabilities to deal with non-Article 5 type of contingencies around Europe's peripheries. This would ultimately help relieve the United States of the burden of guaranteeing Europe's security. With Turkey inside the EU, Washington would find it much easier to deploy its troops in non-European countries that impact U.S. security interests more closely.

Third, Turkey's membership of the European Union would also help the United States win the war on global religious terror in the sense that this would likely strengthen the hands of moderate/liberal Islamic forces and suggest that the U.S.-led war on terror does not aim at Islam, but rather at its radical/fundamentalist interpretations. Turkey's EU membership would help justify the American support for moderate and /liberal Islamic circles in the Middle East and elsewhere. Turkey's EU membership would help prove that Islam and democracy could coexist, a strategic goal on the part of the United States in the 
post 9/11 era. The U.S. fight against radical Islamic movements can be won through the strengthening of liberal Islamists.

Fourth, the United States supports Turkey's EU membership on the grounds that such an outcome would help create a more reliable partner with whom reaching consensus on the basis of rationality would be much easier. Turkey's EU membership would help reduce that republic's unilateral and nationalist tendencies as well as increase the degree of predictability in its foreign policy choices. Hence, the American support to Turkey's EU membership is more realpolitik/strategic/instrumental/imperialist in nature. The goal is to benefit from a Europeanizing or EU-member Turkey in the materialization of imperialistic security interests in Turkey's neighborhood, notably the Middle East.

On the other hand, examining the reasons on the part of Turkey to become a member of the European Union, one can point to the following motivating factors: First, Turkey wants to join the EU in order to escape the possibility of being drawn into the Hobbesian security environment in the Middle East. In Turkey's view, the EU stands for the best example of Kantian security complex, where the possibility of resorting to and use of brute force in interstate relations is at its minimum. Unless Turkey becomes a part of the EU family of nations, the developments in the Middle East, particularly right after the 2003 war in Iraq, would likely harm Turkey's security interests. In this sense, joining the EU would help increase Turkey's ability to resolve its perennial domestic security problems, most important of which is the ongoing ethnic Kurdish separatism. For the rising Kurdish nationalism in northern Iraq not to be seen as a pole of attraction by Turkey's Kurdishorigin citizens, Turkey's membership of the EU has now become the most important strategy to follow. The transformation of Turkey into a liberal democratic country in line with the EU's constitutive norms seems to offer the most credible opportunity for the resolution of Turkey's Kurdish problem at home. It is through this way that Turkey's Kurds could possibly remain loyal to the central political authority in Ankara.

Second, becoming an EU member is also seen as the most important strategy to counter-balance the growing imbalances in Turkey's relations with the United States. As an EU member Turkey would be more able to resist particular U.S. demands. The fact that Turkey's refusal to cooperate with the United States on the eve of the Iraq war in March 2003 was supported by the strong German-French objections to the United States' war aims is a case in point. Turkey's bargaining power vis-à-vis Washington would likely increase following its accession to the EU. ${ }^{14}$ This is a typical realpolitik stance toward the EU. The point that needs to be stressed here is that the more bilateral Turkish-American relations have turned out to be, the more Turkey considered membership in the EU, with a view to balancing the United States. What is noteworthy in this regard is that Ankara's decision of non-cooperation with Washington on the one hand, and the initiation of the accession talks with the European Union on the other hand, has contributed to the rise of Turkey's soft power in the Middle East. This has raised the power of attraction that Ankara holds in the eyes of the Middle Easterners. A Turkey that gets estranged from the EU and draws closer to the United States would most likely lose the moral high ground it has gained over the past five years, as the U.S. image in the region is now in tatters.

Third, Turkey also hopes to check the growing Iranian influence in the Middle East by joining the EU. Turkey's membership in the EU would not lead the regime in Tehran to view Turkey positively, but also it would enable Ankara to outmaneuver Iran in Middle Eastern politics. For Turkey's messages and identity to be received positively in the region, Ankara needs to resolve its perennial problems at home through the EU accession process as soon as possible. Otherwise, Ankara would find it difficult - if not impossible - to defeat the Iranian model. At stake is Turkey's ability to play a leadership role in the Middle East, 
as well as to be seen as a legitimate actor in this regard. In the conceptualization of the governing Justice and Development Party (AKP), Turkey's ability to play a credible leadership role would depend on Turkey's success in transforming into a typical European state at home, as well as increasing its power of attraction in the eyes of the Middle Eastern regimes. For the so-called Turkish model to be viewed positively, membership in the EU would seem to be a facilitating factor.

\section{Divergence of opinions on the future of NATO}

Turkey's institutional ties with the West, which were established only after World War II, have a much shorter lifespan when compared to its history in the West. The role that Turkey assumed within the Western institutional frameworks was mainly an outcome of the entry of the United States into the picture. Prior to that, for the Turks, the West was mainly understood as Europe-which Turkey was not usually considered to be an integral part of. In that context, NATO has not only been the catalyst of powerful alliance relations between Turkey and the United States but also consolidated Turkey's place within Western institutional frameworks. Nevertheless, today NATO has turned out to be another source of controversy between the two countries, in the sense that they differ from each other as to how to define NATO's transformation in the post-Cold War era.

Turkey long valued its membership in NATO, mainly because NATO was a Eurocentric collective defense organization and that its presence in NATO's institutional platforms confirmed the credentials of Turkey's Western and European identity. NATO's legitimacy in the eyes of Turkey has also stemmed from other factors. First, NATO offered Turkey external security guarantees against external threats. Second, Turkey was content with interacting with the United States through the multilateral mechanisms of the Alliance, rather than facing Washington bilaterally. Turkey's bargaining power vis-à-vis the United States increased through its membership in NATO. On many occasions during the Cold War era, Turkey resisted U.S. attempts at endowing the Alliance with a nonEuropean identity and employing it in non-European contingencies. Third, membership in NATO also suggested that Turkey's Western allies respected Ankara's internal affairs.

The post-Cold War era has gradually contributed to the erosion of the factors mentioned above. First, in the absence of the Soviet threat it has become increasingly difficult for NATO members to unite around identical security conceptualizations. The expectation that NATO would automatically come to Turkey's aid in case of external threats was shattered. For example, the European members of the Alliance argued against the deployment of NATO's capabilities in Turkey's southeastern region when Ankara demanded this in order to stave off any Iraqi assault in early 2003. It is now difficult to argue that Turkey solely entrusts its security to NATO. ${ }^{15}$

Second, the transformation of the Alliance-from being a Euro-centered collective defense organization into a non-Europe focused collective security organization - diluted NATO's capability to help confirm Turkey's Western and European identity. Though Turkey did not block NATO's enlargement toward Central and Eastern European countries, as well as its adoption of a more political and less military/strategic identity, Ankara reluctantly gave its green light to such developments. In Ankara's eyes, NATO's strategic identity should not have been diluted, for the more political NATO became, the more Turkey's Western allies would find it legitimate to interfere with Turkish internal affairs.

Third, Turkey has grown discontented with the possibility that NATO has gradually turned out be a strategic tool in the hands of the United States concerning the extension of 
America's sphere of influence in traditionally non-European geographies. Americanization of the Alliance at the expense of its European character has also eroded Turkey's ability to interact with the United States multilaterally. Turkey's bargaining power vis-à-vis the United States decreased as the latter has begun to see NATO as less relevant to its postCold War era security strategy. No doubt the desire of the European members of the Alliance to politically counterbalance the United States within NATO, despite their failure to improve their military capabilities of interoperability with U.S. forces, has shaped America's reluctance to rely on NATO. As the United States has begun to view NATO as a constraint on its ability to act independently, Turkey's ability to help shape American policies has decreased.

Turkey had also some serious reservations concerning NATO's eastward enlargement closer to Russia. In the eyes of Turkish strategists, NATO's eastward enlargement in the absence of an existential Soviet threat would amount to a provocative American initiative vis-à-vis Russia. ${ }^{16}$ That Russia has adopted a more nationalistic, anti-Western and authoritarian character over the last decade can be confidently attributed to the American initiatives to contain Russia through NATO's enlargement toward the former members of the Warsaw Pact in Central and Eastern Europe such as Hungary, Poland, the Czech Republic, and Slovakia, as well as in the Balkan nations, such as Bulgaria and Romania, which have already joined the ranks of the Alliance structure, while others like Albania and Croatia are on the waiting list.

Russia, which could not afford anything more than threatening statements over the past decade with a view to preventing NATO's eastward enlargement, due to the serious difficulties in its political, economic and military spheres, finally said "enough is enough" - anticipating further expansion of the zone of influence of the United States into its immediate hinterland, which was formally declared Russia's "near abroad" back in 1993. Russian military intervention in Georgia in August 2008, followed by its formal recognition of the proclamation of independence of South Ossetia and Abkhazia can be seen, among other steps, as a manifestation of the resolve of the Russian authorities to put an end to NATO's enlargement toward its frontiers, and to seal the boundaries of the Russian zone of influence in the decades ahead, which will most likely encompass Belarus, Moldova, Georgia and Ukraine. The designs of the United States to project its military might into Eastern Europe with its "missile shield", and to Southeast Europe and the Black Sea basin with its naval assets, have deeply disturbed Russia. Hence, Turkey's immediate northern neighborhood has become the focus of tension between Russia and the United States. Whether or not such a development will have potential repercussions, such as the flexing of the muscles of these two military giants in the region, remains a much speculated question. Given that Turkey has invested a lot in improving its own relations with Russia in the post-Cold War era, the growing tension between the West and Moscow would not be easily tolerated by Ankara.

\section{Conclusion}

This paper has argued that two staunch allies of the recent past-namely Turkey and the United States - stand at the threshold of a rivalry, unless proper measures are taken. It is interesting to note that the potential rivalry stems not from diverging strategic objectives. On the contrary, the grand strategic objectives of the United States and Turkey overlap almost perfectly - such as fighting against international terrorism, limiting the spread of political Islam, spreading democratic values to the Third World, advancing Turkey's European vocation, expanding NATO's role in the world, and constraining further military 
intervention by Russia in the region. However, the ways and means of achieving these objectives become serious bones of contention, which degrade the value of cooperation between Turkey and the United States. Both parties take rather guarded positions vis-à-vis each other, instead of searching for ways of further collaboration in order to quickly and more effectively achieve their geopolitical and geostrategic objectives. Lack of trust is definitely one particular source of skepticism about each other's intentions. However, even if the parties overcome the problem of lack of trust, structural reasons exist emanating from approaching the issues from almost opposite angles regarding the ways and means of achieving their goals.

The crisis in the Caucasus serves as a serious test case, both for Turkey and the United States, to see if they have again a common denominator for a strategic partnership in the future. At first glance, logic may suggest that, because the end of the Cold War is said to have caused the gradual deterioration of Turkish-American relations due to the absence of common strategic interests as a result of the disappearance of the Soviet threat, then the "revival of the Cold War", as argued by many after the Russo-Georgian confrontation, may help Turkey and the United States put aside their differences on thorny issues (e.g. the implications of the American invasion of Iraq and its support to the northern Iraqi Kurds; or its desire to promote Turkey as a role model in the Islamic world for promoting its democracy project in the Greater Middle East), and to act again as "staunch allies" against the "common threat" of Russia.

Due to the sharp and steady increase in oil and natural gas prices over the past several years, the Russian economy recovered enormously from the collapsing financial situation of the 1990s. With the confidence gained, thanks to the boosting of its economic and financial growth, some leading Russian security analysts started to claim that "the days of misery are over and Russia strikes back." "Therefore, the Russian military intervention in Georgia did not come as a surprise to outside observers who have lately been following the changing patterns in the foreign and security policies of Russia, which reminded many analysts of the period of Cold War politics.

It is worth remembering that the rhetoric of the "revival of the Cold War" owes much, among others, to the confrontational steps that were taken by the United States and Russia following the passage of the American naval vessels through the Turkish Straits into the Black Sea for carrying "humanitarian help" to Georgia. In some respects, the move of the United States into the Black Sea basin with its maritime power may be compared to the visit of the battleship USS Missouri to Istanbul back in 1946, or to the NATO summit decision in Rome in 1959 requiring Turkey to host U.S. nuclear weapons, both of which were considered to be powerful symbols of the strategic relations between Turkey and the United States that lasted for decades. These dramatic developments in the past have not disturbed Turkey's strategic interests in the region. Rather, they forged Turkey's position vis-à-vis a powerful neighbor, namely, the Soviet Union, that had threatening designs over the Turkish Straits and also territorial claims on Turkey's eastern provinces.

However, today the situation is different. It is true that, despite the rapidly growing political and economic ties between Turkey and Russia, most Turks still consider their centuries-old northern neighbor as a potential threat, possibly under the influence of historical events. Yet, the U.S. designs over the Black Sea basin are considered by the Turkish security elite in particular as posing a serious challenge to Turkey's interests, regardless of whether Russia is in the picture or not. This is because of the Montreux Convention of 1936, which underpins the sovereignty of Turkey over the Straits and also regulates and puts restrictions on the passage of military vessels that belong to countries that are not littoral to the Black Sea. 
The United States has long expressed its desire to station a maritime power in the Black Sea, as part of its global "war on terror," on the grounds that this region has become the focus of illegal trafficking activities of lethal weapons and/or special material that may be used in the manufacture of such weapons, including weapons of mass destruction. Therefore, the United States has accelerated its efforts to convince its NATO allies that adjoin the Black Sea to host American military ships in their ports. Bulgaria and Romania, two new NATO allies, have been quite receptive to the idea of providing such logistical support by opening their ports to the United States. But, Turkey and Russia opposed this proposal on the grounds that such a development would possibly render the Montreux Convention ineffective, because there are strict and specific limitations on the tonnage of the military ships that may pass through the Turkish Straits, and also on the number of days that these ships may stay in the Black Sea.

Regarding the U.S. strategy in its global war on terror, Turkey as well as Russia can anticipate that the presence of American military ships in the Black Sea will be for extended periods, once they have arrived in the region, by finding some ways and means to do so, benefiting from loopholes in the Montreux Convention. Turkey fears that with the collaboration of some littoral countries, such as Romania and Bulgaria, the terms of the Convention may be interpreted is such a way as to serve the interests of the United States. From Turkey's perspective, such an eventuality may pose a challenge to the Montreux Convention, both in terms of the tonnage limitations and also in terms of the periods that the Americans would like to stay in the region. This raises the question of why Turkey is so sensitive about the decades old status quo that has been built around the Montreux Convention.

The Montreux Convention is considered by most Turks as one of the greatest diplomatic victories gained in the international arena in the history of the Republic of Turkey, which was proclaimed as an independent state on October 29, 1923 following the signing of the Lausanne Peace Treaty on July 24, 1923. There were several issues that could not be agreed upon among the negotiating parties at the Lausanne conference that was convened following the Turkish military victory the occupying powers, such as Britain, France, Italy and Greece that had partitioned the Ottoman Empire in the aftermath of World War I. These were the territorial claims of Turkey on the formerly Ottoman territories, such as the Mosul province (today's northern Iraq) that was given to the British mandate by the League of Nations, and the Hatay province that was left to the French mandate. Another outstanding issue that remained unresolved at the Lausanne negotiations was the dispute over Turkey's sovereignty over the Straits of the Dardanelles and the Bosphorus, which had long been administered by an international commission. Because of the Russian claims on the Straits, finding a solution could not be possible until the mid1930s. When the time was ripe, Turkey took another initiative to bring the issue to the fore in 1935. It must be acknowledged that the stance of the United States that favored Turkey's arguments was particularly effective in reaching a solution in the negotiations held in Montreux, Switzerland. One might argue that behind the U.S. support lent to Turkey on this particular issue were the strategic calculations of American policymakers about the war that could be seen approaching on the horizon with Hitler's rise to power in Germany, and also about the post-war period.

In the 1930s, U.S. policies concerning the Turkish Straits served the vital strategic interests of Turkey very well. Today, however, the situation is dramatically different. Being heavily concerned with the possible impact on the Montreux Convention of the U.S. desire to advance its maritime power into the Black Sea region, Turkey seems to be adopting a position that is similar to that of Russia. However, the high degree of similarity of the 
Turkish and the Russian positions regarding the Montreux regime should not be misinterpreted. It would be a far fetched scenario to argue that Turkey and Russia are building up a unified front against the United States. Rather, Turkey is trying to benefit from the similarity of positions with Russia to diminish the appetite of the United States that may take steps in the Black Sea posing a challenge to the effectiveness of the Montreux Convention that may eventually bring up the question of who should control the Straits. Should this happen, no matter how unlikely a scenario it may seem to be now, Turkey's sovereignty, independence and territorial integrity may be at stake.

Against this background, it can be seen that the U.S.-Russian confrontation in the Black Sea basin will not necessarily lead to the resuscitation of the strategic partnership between Turkey and the United States. Moreover, the rift between the United States and Russia may turn out to be another bone of contention between Turkey and the United States that may set the two allies further apart. What remains to be done for the Turks and the Americans at this stage should be to appreciate each other's serious concerns about the threats that they perceive. Diplomacy is the art of finding solutions to the most difficult problems. For this to happen, there must be political will and determination on both sides.

The Turks and the Americans must bear in mind that the world will be a much less safer place for either party when they are not friends. The answer to the question as to whether Turkey and the United States will remain friends or become foes in the twenty-first century should be found as soon as possible, for the recent signs of improvement prior to the crisis in the Caucasus might not survive against the strategic divergences that are likely to sharpen with the rhetoric of the "new Cold War."

\section{Notes}

1. The German Marshall Fund of the United States conducted research on transatlantic trends in 2006 and found that the majority of Turkish people did not view Iran as a threat and found the idea of use of force against Iran, unfavorable: see http://www.transatlantictrends.org/trends/doc/ TT07KFR_FINAL.pdf (see p.11).

2. Elbridge Colby, "Restoring Deterrence," Orbis 51, no. 3 (Summer 2007): 413-28.

3. Gabe Mythen and Sandra Walklate, "Terrorism, Risk and International Security: The Perils of Asking What If?" Security Dialogue 39, nos. 2-3 (2008): 221-42.

4. Robert Kagan, "Power and Weakness: Why the United States and Europe See the World Differently," Policy Review, June-July 2002.

5. Milliyet, March 24, 2007. Eighty-seven percent of the Turkish people thought that the main reason for the continuation of the PKK threat for so long is the involvement of external actors in the dispute and the active support that PKK receives from outside sources.

6. Ronald R. Krebs, "Rethinking the Battle of Ideas: How the United States Can Help Muslim Moderates," Orbis (Spring 2008): 332-46.

7. Meliha B. Altunisik, "The Possibilities and Limits of Turkey's Soft Power in the Middle East," Insight Turkey 10, no. 2 (2008): 41-54.

8. E. Fuat Keyman, "Modernity, Secularism and Islam. The Case of Turkey," Theory, Culture \& Society 24, no. 2, (2007): 215-34.

9. Daniel S. Hamilton, "The United States: A Normative Power?" Center for European Policy Studies, Working Document no. 291 (May 15, 2008).

10. Philip Gordon, "Winning the Right War," Survival 49, no. 4, (2007-8): 17-46.

11. Charles Kupchan, "Europe and American in the Middle East," Current History (March 2007): 137-9.

12. Pinar Bilgin, "Only Strong States Can Survive in Turkey's Geography: The Uses of Geopolitical Truths in Turkey," Political Geography 26 (2007): 740-56.

13. Omer Taspinar, "Turkey's Fading Dream of Europe," Current History (March 2007): 123-9.

14. Joshua W. Walker, "Reexamining the U.S.-Turkish Alliance," Washington Quarterly 30, no. 4 (Winter 2007): 93-109.

15. German Marshall Fund poll on transatlantic trends. 
16. Ali L. Karaosmanoğlu, "NATO Enlargement and the South: A Turkish Perspective," Security Dialogue 30, no. 2 ( June 1999): 213-24.

17. Among those who put forward similar arguments, Dimitri Trenin from the Carnegie Endowment's Moscow office expressed these views during the working group sessions of the Black Sea Security Conference held in Bucharest, Romania in February 2006.

\section{Notes on contributors}

Mustafa Kibaroglu (Ph.D., Bilkent University) teaches courses on "Arms Control \& Disarmament" in the Department of International Relations at Bilkent University in Ankara (since 1997). Dr. Kibaroglu is also the Academic Advisor for the NATO Centre of Excellence Defence Against Terrorism, which was established in Ankara in 2005 under the auspices of the Turkish General Staff. Dr. Kibaroglu is the co-author of Global Security Watch - Turkey to be published by Praeger in 2009, and the editor of Turkey's Neighborhood (2008). He is also the author and co-author of numerous chapters in books and articles in journals, such as Security Dialogue, The Nonproliferation Review, The Bulletin of the Atomic Scientists, Middle East Quarterly, Middle East Journal, Brown Journal of World Affairs, Middle Eastern Studies, and Middle East Policy. His research interests are focused on issues relating to the proliferation of weapons of mass destruction, Middle Eastern politics, and Turkish foreign policy.

H. Tarik Oguzlu (Ph.D., Bilkent University) is currently an Assistant Professor in the Department of International Relations at Bilkent University in Ankara (since 2003). Dr. Oguzlu holds a MSc. degree from the London School of Economics and Political Science in 2000 and an MA degree from Bilkent University in 1998 both in the fields of International Relations. He was granted a Jean Monnet scholarship by the European Commission in 1999. Dr. Oguzlu teaches courses on international relations theories, international politics, European security and defense policies, and Turkey's relations with the European Union. He has academic articles published in such journals as Middle East Policy, Security Dialogue, Middle Eastern Studies, Turkish Studies, Cambridge Review of International Affairs, Contemporary Security Policy, and the Australian Journal of International Affairs. 